\title{
Urban Surveillance
}

\author{
The Hidden Costs of Disneyland \\ Timothy Stanley, The University of Manchester, United Kingdom
}

\begin{abstract}
Surveillance takes many shapes and forms and the experience of surveillance is often most intense in urban centers. One of the historical roots of surveillance can be connected to the modern information base of tracking individuals for economic and political reasons. Michel Foucault comments in more detail on one of the earliest examples of a surveillance machine found in Jeremy Bentham's Panopticon. Surveillance has now become the solution of choice to ward off urban fears and insecurities in today's megacities. Though its antecedents can be traced via Foucault's account of panoptic discipline which walled in society's outcasts for rehabilitation, the following essay explores the shift to the urban panopticism of today where society's outcasts are subtly filtered out of "public" view. Juxtaposing a sociological account of the concentration camp with urban Disneyization fosters a greater understanding of how surveillance creates certain categories of citizenship. In particular, how urban surveillance intensifies Walter Benjamin's description of the flaneur who often experiences the brunt of surveillance's filtering power.
\end{abstract}

Keywords: Surveillance, Urban, Disney, Flâneur, Foucault, Panopticon

$\mathrm{S}$ URVEILLANCE IS ONE of the most common experiences we share today. For instance, let's look at something as simple as grocery shopping. Walking in, a TV above your head let's you know you're on camera. Checking out, if you use a debit card your purchase is tracked. If you use a club card each item you buy is tracked. If you've ever used online shopping for instance, your first visit asks you for your club card number. After entering it the website tells you everything you've ever bought at that store.

Another common experience we all share to one degree or another is the global renovation of urban centers. For instance, I currently live in Manchester, England, which was once a harbinger of the industrial revolution. Now however, it has become a consumer tourist center full of trendy shops, museums, theatres and parks. Marshal Mcluhan prophesied this urban transition as the shift from industry to Disneyland. Some 40 years ago now, sitting in the patio of a NY restaurant, he circled his finger around the skyscrapers above his head and proclaimed: "of course, a city like New York is obsolete. People will no longer concentrate in great urban centers for the purpose of work. New York will become a Disneyland, a pleasure dome ... You're Gonna Love Gothamland."1

What is often unnoticed however, is how the Disneyization of cities like Manchester goes hand in hand with surveillance. Surveillance is often billed as a community building mechanism that will help keep our cities safe and prosperous. What I want to explore are the political and sociological antecedents of the relationship between urban Disneyization and surveillance. Though surveillance is being used in Disneyland, it is also being used in concentration and prison camps. However, the logic of surveillance has been inverted as surveillance has developed from concentration camps to what I will be calling Disney camps. To understand urban surveillance more fully I will briefly explicate the following five points:

- Definitions of Surveillance

- Political Correlations

- Concentration Camps

- Disney Camps

- The Hidden Costs

\section{Definitions of Surveillance}

Firstly, when we are examining surveillance it's important to note that surveillance technologies are focused on personal information. So being caught on camera is one of a plethora of ways in which we are tracked - for instance, DNA, fingerprints, retina scans, voice recognition, shopping habits, body mechanics (the way each person has a unique way of moving based on their body's mechanics, e.g. bone lengths and joint constructions). Secondly, the personal information being captured will be surveillanced by a machine - that is, it's mechanized. As such it is part of what might more broadly be

\footnotetext{
${ }^{1}$ Tom Wolfe, "Pleasure Principles," New York Times, June 122005.
} 
affiliated with the culture of modernity, or something akin to what we might call the machine age.

One of the first machines used for surveillance was an architectural building plan called the panopticon. Jeremy Bentham was one of the first to write about the panopticon which was essentially a round building with an inner tower at its center. The exterior of the building was made up of a series of cells which all faced the central tower. The tower was designed such that someone - a prison warden, or an employer - could be in the tower and see everyone working in the building from his or her central vantage point. Crucially however, those in the cells would not be able to see if anyone was in the tower or not. Bentham had designed the windows of the tower with a system of shutters so that prisoners or employees wouldn't be able to see if anyone was watching. Bentham elatedly describes his building as follows: "morals reformed - health preserved - industry invigorated - instruction diffused - public burdens lightened - Economy seated as it were upon a rock - the Gordian knot of the Poor-Laws not cut but untied - all by a simple idea in Architecture!",2 Bentham wanted to reform morals, make the economy more efficient, and had an overarching political agenda which he believed his machine/building could carry out in the most efficient way possible.

Michel Foucault goes into more detail into the way the panopticon worked by looking at the way it shaped and influenced those who lived or worked in the cells. The feeling of being watched had the ultimate effect of fostering self-discipline in its subjects. Because the experience of being watched was unverifiable, those under the gaze of the tower would police themselves. Because you might be seen, you therefore had to discipline yourself. Foucault argues that this means that the experience of surveillance is interiorized: "an inspecting gaze, a gaze which each individual under its weight will end by interiorizing to the point that he is his overseer, each individual thus exercising this surveillance over, and against, himself."3

This interiorization of the gaze creates a certain kind of subjectivity, or to put it more broadly, fosters a certain kind of citizenship. So surveillance, as it is defined here, encompasses the various mechanized ways individuals are catalogued and managed such that they are aware of it, but unable to verify exactly when it is taking place. This creates the internalized sense in which individual people police themselves.

\section{Political Correlations}

The first thing I want to highlight is how the mechanized analogies which were being employed in the fields of physics and biology - e.g. Newtonian physics - began to inform political theorists such as Thomas Hobbes and Jean-Jacques Rousseau. As such, there are important correlations that can be drawn between their political theories and the mechanized panopticism noted by Foucault. One of the first and most influential articulations of mechanized politics can be found in Thomas Hobbes's, Leviathan. Hobbes was the first to make the shift from an Aristotelian understanding of human beings as political animals, to the belief that human beings were caught up in a political machine. In the introduction to Leviathan, Hobbes draws the analogy between a mechanized view of the human body with the heart being like a spring in a clock, and the political body, or commonwealth which in like manner was seen as an autamata. ${ }^{4}$ Hobbes stands as a crucial point in western political history because of the influence of the shift he made. As Amos Funkenstein puts it, "The most important political thinkers since the seventeenth century did not reject him outright even if they were profoundly irritated by his claims. Instead, they absorbed the full force of his arguments before transforming them into a different, sometimes even a contrary, theory." 5

Such was the case with Jean-Jacques Rousseau. Rousseau disagreed with Hobbes's account of humanity as nasty and brutish ${ }^{6}$ and saw this as a position skewed by a need to justify the rule of a sovereign king. In contrast, Rousseau argued that political problems such as corruption and coercive uses of power are societal. The natural state of human beings was essentially free. As he says, "man is born free, and everywhere he is in chains."7 Thus society

\footnotetext{
2 Jeremy Bentham, Panopticon (London: Reprinted and sold by T. Payne, 1791). i-ii Full Title: or, the Inspection-House; containing the idea of a new principle of construction applicable to any sort of establishment, in which persons of any description are to be kept under inspection; and in Particular to Penitentiary-houses, Prisons, Houses of industry, Workhouses, Poor Houses, Manufacturies, Madhouses, Lazarettos, Hospitals, and Schools; with a plan of management adopted to the principle; in a series of letters, written in the year 1787, from Crechoff in White Russia, to a friend in England. First published: (1 volume, Dublin, Thomas Byrne, 1791; 2 volumes, London, T. Payne, 1791)

${ }^{3}$ Michel Foucault, Power/Knowledge: Selected Interviews and Other Writings, 1972-1977, ed. Colin Gordon (New York: Pantheon Books, 1980). 155

${ }^{4}$ Thomas Hobbes, Leviathan, ed. Alfred Rayney Waller (Cambridge: Cambridge University Press, 1904). xviii

5 Amos Funkenstein, Theology and the Scientific Imagination from the Middle Ages to the Seventeenth Century (Princeton: Princeton University Press, 1986). 327

6 "And the life of man, solitary, poore, nasty, brutish, and short." Hobbes, Leviathan. 82

7 Jean J. Rousseau, The Social Contract: Or Principles of Political Right (Ware: Wordsworth Editions Limited, 1998). 5 First published in 1762. it was censured early on.
} 
was enslaving human beings, and it was society that ought to be changed. Hence, Rousseau's emphasis upon a social contract that individuals could agree upon, and in all agreeing together, be ruled by the sovereignty of their general will rather than a sovereign king. Rousseau argues that when individuals submit their particular wills to a general will they become self ruled. In Rousseau's words: "In short, each giving himself to all, gives himself to nobody." 8 Furthermore, if an individual breaks the contract with the general will, because the rule of all is the condition for freedom, the society as a whole can legitimately compel an individual to be free. Rousseau puts it this way: "In order then that the social compact may not be an empty formula, it tacitly includes the undertaking, which alone can give force to the rest, that whoever refuses to obey the general will shall be compelled to do so by the whole body. This means nothing less than that he will be forced to be free; for this is the condition which, by giving each citizen to his country, secures him against all personal dependence. In this lies the key to the working of the political machine; this alone legitimises civil undertakings, which, without it, would be absurd, tyrannical, and liable to the most frightful abuses."9

However, in arguing for a social contract or the sovereign rule of a general will, a catch 22 emerges in Rousseau's thought. Which comes first, the perfect citizen who creates the perfect society or the perfect society that pops out of the sky and forms the perfect citizen? ${ }^{10}$ If the perfect society causes or draws out inherent human goodness, then who starts it if society is currently riddled with contradictions and evils? Rousseau's solution is to tentatively posit a benevolent legislator who makes the laws that get the ball rolling. The legislator is epitomized as a dispassionate observer whose happiness does not depend on the citizen's practices but is distanced and selfless. 11 Rousseau says: "Thus we find simultaneously in the work of legislation two things that seem incompatible - an enterprise surpassing human powers, and, to execute it, an authority that is a mere nothing." 12 Both the dispassionate distance of the legislator and the ideal of an authority that functions according to a "nothing" or without the exercise of real force are required by Rousseau so that the legislator doesn't become a sovereign power himself.

Although Rousseau admits that his legislator appears somewhat paradoxical if not completely unrealistic in any way, I'd like to suggest that if we return to the opening pages of Jeremy Bentham's Panopticon an interesting correlation can be discerned. "Morals reformed - health preserved... all by a simple idea in Architecture!"13 By a feat of architecture, technology, and mechanization the paradox of holding individual freedom and a sovereign general societal will together is realized. The general will becomes self-disciplined automata under the panoptic gaze. The legislator is able to be positioned in the center as the omniscient eye who watches and enforces his law through the panoptic element rather than coercive physical force.

Rousseau's social contractualism beckons much more detailed explication than I am offering, but the implications of the conflation of Rousseauist political theory and panopticism are crucial for our purposes here. Surveillance atomizes individuals in order to make them a collective. It has to atomize human beings so that they can be identified positively, whether in a cell, or, as in today's surveillance societies, on camera. As Foucault puts it, surveillance "arrests or regulates movements; it clears up confusions... it establishes calculated distributions."14 Because of the way panopticism tracks and sorts, however, it is fundamentally disinterested. These aspects of panopticism fit nicely with the way Rousseau has to maintain disinterestedness so that no one individual will be ruled by another. Rather, in each individual giving themselves to all, they rule themselves. The legislator is the chief example of how this mechanized distance is required. There can be no king for Rousseau. Rather, the sovereignty of the king is internalized into the contractual body of the machine. Rousseau consistently argues for the rule of the general will of all at the expense of the particular will of individuals.

\footnotetext{
${ }^{8}$ Ibid. 15

${ }^{9}$ Ibid. 18

${ }^{10}$ Derek Matravers, "Introduction," in The Social Contract: Or Principles of Political Right (Ware: Wordsworth Editions Limited, 1998). xiii

11 "In order to discover the rules of association that are most suitable to nations, a superior intelligence would be necessary who could see all the passions of men without experiencing any of them; who would have no affinity with our nature and yet know it thoroughly; whose happiness would not depend on us, and who would nevertheless be quite willing to interest himself in ours; and, lastly, one who, storing up for himself with the progress of time a far-off glory in the future, could labor in one age and enjoy another. Gods would be necessary to give laws to men." Rousseau, The Social Contract: Or Principles of Political Right. 40

12 Ibid. 42 Italics added.

13 Bentham, Panopticon. i-ii

${ }^{14}$ Michel Foucault, Discipline and Punish: The Birth of the Prison, 2nd Vintage Books ed. (New York: Vintage Books, 1995). 219 For a more current appropriation of this notion see also, Hille Koskela, "The Gaze without Eyes: Video Surveillance and the Changing Nature of Urban Space," in Virtual Globalization: Virtual Spaces/Tourist Spaces, ed. David Holmes (London: Routledge, 2001). 137 where she describes malls and consumer centers as exclusionary public spaces. See also Peter Marcuse, "Not Chaos, but Walls: Postmodernism and the Partitioned City," in Postmodern Cities and Spaces, ed. Katherine Gibson (Oxford: Blackwell, 1995). 243ff
} 
Even when he tempers these statements with the belief that the two wills should coincide, when panopticism is employed alongside Rousseauist political theory the combination can easily become a self-justified mechanism used to "force individuals to be free."

\section{Concentration Camps}

Bentham actually struggled to get his building built in the early nineteenth century, but the panopticon did eventually take root in Western society. When we look at the layout of many prisons or concentration camps, the basic premise of panoptic observation can be discerned. Zygmunt Bauman postulates that the twentieth century may be remembered as a century of camps. ${ }^{15}$ In his view the holocaust, far from being an abnormality, was in fact a continuation of the logic of modernity. In his words: "Neither the Nazi nor the Communist vision jarred with the audacious self-confidence and hubris of modernity; they merely offered to do better, and more ruthlessly (but more speedily in its result), what other modern powers dreamed of, perhaps even tried, but failed or did not have the guts to accomplish." 16

In orderly systematic fashion the Holocaust carved strangers out as the abnormal dissidents of society, corralled them into ghettos, and systematically exterminated them. Camps were the Rousseauist belief in order and perfect humanity brought into brutal reality. The panopticon was used as the chief means to force society's outcasts to be free, and if, as in the case of the Jews under Nazi rule, they could not conform to the general will then they could be discarded. Surveillance was employed to create the general will and the great society not through the logic of the dungeon, but through the logic of selfdiscipline. The outcasts that were deemed not to conform to the sovereign rule of all were separated out for purification.

In order to understand surveillance in the form of a concentration camp we need to look at the experience of those under its gaze. What kind of people are these camps shaping and influencing? What status do citizens have in the concentration camp? To answer these questions I want to explore what Giorgio Agamben refers to as homo sacer - the sacred human whom "the people have judged on account of a crime. It is not permitted to sacrifice this man, yet he who kills him will not be condemned for homicide." 17 Homo sacer is a somewhat paradoxical term in that it makes individual subjects sacred, un-sacrificable, and yet open and bare before the threat of death. Though Agamben's interpretation of this category is far from infallible, ${ }^{18}$ it represents an interesting insight into the logic of the concentration camp. ${ }^{19}$ The sovereign power of the general will of the collective is formulated in the workings of the panoptic machine which seeks to ideologically inculcate individual subjects into its whole. Each subject is related to each other like cogs and springs designed to work together to produce the perfect society for all at the expense of those forced into the camp.

What is key about homo sacer however, is that this term creates a space of exception, a no-man'sland where human life as a citizen is reduced to biology. Thus biopolitics is born in the conflation of bare life with sovereign power such that nothing becomes impossible, nothing becomes illegal. ${ }^{20}$ This helps make sense of how the holocaust, and in Agamben's latest work, Guantanimo Bay, can become possible. Those under the panoptic gaze take on a unique form of subjectivity. Those deemed to be homo sacer, to be bare lives without humanity, can, in the name of the general will, be "made to be free" in a holy state of exception where "the care of life coincides with the fight against the enemy." 21 Homo sacer, as the societal outcast, experiences the full brunt of surveillant power concentrated in the experience of the camp. The perfect society exists outside the camp, made possible by the expulsion of the outcasts who are being disciplined, rehabilitated, interrogated, or simply removed, full stop. The concentration camp represents one of the most pervasive uses of surveillance over the past century

\footnotetext{
${ }^{15}$ Zygmunt Bauman, The Bauman Reader, ed. Peter Beilharz, Blackwell Readers (Oxford: Blackwell Publishers, 2001). 280 This is from Bauman's work Zygmunt Bauman, Modernity and the Holocaust (Ithaca: Cornell University Press, 2000). Bauman is not the only one to make this connection, however his is an early account. See also Giorgio Agamben, Homo Sacer: Sovereign Power and Bare Life, trans. Daniel Heller-Roazan (Stanford: Stanford University Press, 1998). "Today it is not the city but rather the camp that is the fundamental biopolitical paradigm of the West." 181

${ }^{16}$ Bauman, The Bauman Reader. 274

17 "In the first tribunitian law, in fact, it is noted that 'if someone kills the one who is sacred according to the plebiscite, it will not be considered a homicide.' This is why it is customary for a bad or impure man to be called sacred." Agamben, Homo Sacer: Sovereign Power and Bare Life. 71 citing Pompeius Festus, On the Significance of Words. Sacer mons

${ }_{18}$ Agamben himself notes the various interpretations offered for this term. Agamben, Homo Sacer: Sovereign Power and Bare Life. $71 \mathrm{ff}$. Those having read his work have in their own ways teased it out. See for instance Slavoj Zizek, Welcome to the Desert of the Real! (London: Verso, 2002). 100ff, and John Milbank, Being Reconciled: Ontology and Pardon, Radical Orthodoxy Series (New York: Routledge, 2003). $90 \mathrm{ff}$

${ }^{19}$ Agamben also explores the concentration camp as a dominant aspect of modern politics and life. See "The Camp as 'Nomos' of the Modern" in Agamben, Homo Sacer: Sovereign Power and Bare Life. 166ff

20 Ibid. 159

21 Ibid. 147
} 
and continues today, but it is at this point that I want to turn to look at how the logic of the concentration camp has morphed into today's urban Disneylands.

\section{Disney Camps}

Urban life and culture have undergone dramatic changes over the last fifty years. The cities of the nineteenth and early twentieth centuries were largely industrial powerhouses of capitalist manufacturing. Over time social patterns allowed people to move from the center of cities out into suburban areas. As the metropolitan area of cities expanded, industrial businesses relocated and the inner cities slowly disintegrated. The industrial center became dirty, corrupt, crime ridden which only accelerated urban flight. ${ }^{22}$ However, there have been a series of urban renewal projects designed to rebuild and refurbish new "fantasy cities." Disneyland is by and large the best correlate of this new urbanism. In fact, "Disney parks have been taken to represent 'a whole approach to urban planning.",23 The Disney approach has produced museums, theatres, restaurants, and shopping venues themed around experiential entertainment like Hard Rock Café, Nike Town and various other shopping venues like the West Edmonton $\mathrm{Mall}^{24}$ and yes, downtown Manchester.

However, the Disneyization of urban centers functions in the wake of the city's dark and derelict past. The rise of terrorism only compounds the concerns new urban dwellers have when moving to, and shopping within, the city center. In facing these circumstances citizens and politicians alike have tended to grab at the most economical and efficient means of alleviating what Zygmunt Bauman calls their "ambient fear." 25 The ambient fear works its way out as an insatiable quest for safe clean "community." As a result, even though the Disney city appears fantastical, chaotic and pluralistic "underneath the chaos there are orders; the fragmentation is not random." 26 And it is for these reasons that surveillance is such a popular partner of Disney cities.

David Lyon, a prominent commentator on surveillance notes that the connection between "Disneyization with surveillance is seldom made, and yet this is the very mechanism that realizes the power of social control. Disneyland itself is safe and squeaky clean because it is patrolled by innocent looking extras who maintain constant surveillance.",27 Various forms of surveillance watch and maintain order in the Disney city and, as in gated communities and shopping malls which are increasingly modeled after principles of Disneyization, ${ }^{28}$ people feudalistically pay for the protection of their land, possessions and the "freedom" to consume. ${ }^{29}$ The principles of consumerism have taken on particular influence in shopping centers and cities modeled on Disneyization. In many cities, "it is only residents' capacity to consume that is viewed as in any sense significant or important." 30 Once inside the confines of the surveillanced space social theorists have found that, "one must always look as if one has bought something, or is about to buy, ${ }^{31}$ because presumed non-customers (such as bag ladies, the homeless or teenagers) 'will be asked to move on or will be thrown out." ${ }^{32}$ The spaces of consumption become 'aestheticized' by exclusion ${ }^{33}$ and, as with the

\footnotetext{
22 This largely represents the use of "urban studies" as the study of the urban poor who couldn't afford to flee into the suburbs. Cities in this sense fit the modern concentration/internment camp scenario where the government built social housing for the socially disadvantaged which created a central area for them to live and exist apart from everyone else. The great society was to be created by providing the spaces for everyone to live. In Burgess's account, for instance, he gives a neatly ordered centripetal pattern emanating out of the center of the city. At its center is the factory zone, then the zone of transition, the zone of workingmen's homes, the residential zone and finally at the perimeter the commuters' zone. Ernest W. Burgess, "The Growth of the City," in The Blackwell City Reader, ed. Sophie Watson, Blackwell Readers in Geography (Oxford: Blackwell Publishers, 2002). 245

23 A Bryman, "The Disneyization of Society," The Sociological Review 47, no. 1 (1999). 27 citing S. Warren, "Disneyfication of the Metropolis: Popular Resistance in Seattle," Journal of Urban Affairs 16 (1994). 90

${ }^{24}$ John Hannigan, "Fantasy City: Pleasure and Profit in the Postmodern Metropolis," in Readings in Urban Theory, ed. Scott Campbell (Oxford: Blackwell Publishers, 2001). 305-24. Here Hannigan outlines in more detail the various ways shopping, education, and restaurants have all undergone radical restructuring around the principles of the theme park and fast food industries.

${ }^{25}$ Bauman, The Bauman Reader. 205

${ }^{26}$ Marcuse, "Not Chaos, but Walls: Postmodernism and the Partitioned City." 244

27 David Lyon, Surveillance Society: Monitoring Everyday Life, Issues in Society (Buckingham: Open University Press, 2002). 55-56

28 "The fastest growing type of 'community' in the United States is the gated community. Twenty-eight million Americans now live in such areas. Over 30 percent of residential development in southern California is not in this form." Timothy Gorringe, $A$ Theology of the Built Environment: Justice, Empowerment, Redemption (New York: Cambridge University Press, 2002). 177

${ }^{29}$ For a detailed description of the "embedded, preventative, subtle, co-operative" surveillance apparatuses used to control visitors to Disneyworld see Clifford D. Shearing and Philip C. Stenning, "From the Panopticon to Disneyworld: The Development of Discipline," in Perspectives in Criminal Law: Essays in Honour of John Ll.J. Edwards, ed. Anthony N. Doob (Aurora: Canada Law Book, 1984). 342ff ${ }^{30}$ Bryman, "The Disneyization of Society." 27 citing Warren, "Disneyfication of the Metropolis: Popular Resistance in Seattle."

${ }^{31}$ R. Shields, "Social Spatialization and the Built Environment: The West Edmonton Mall," Environment and Planning D: Society and Space 7 (1989). 160

32 D. R. Judd, "The Rise of the New Walled Cities," in Spatial Practices: Critical Explorations in Social/Spatial Theory, ed. D. C. Perry (Thousand Oaks: Sage, 1995). 149

${ }^{33}$ N. Duncan, "Renegotiating Gender and Sexuality in Public and Private Spaces," in Bodyspace: Destabilizing Geographies of Gender and Sexuality, ed. N. Duncan (London: Routledge, 1996). 129
} 
disembodied experience of much telecommunication today, the urban experience in the mall is sanitized and 'purified.",34 35 The Disneyized city no longer holds to the vision of the general will of all, but rather has settled for the safe community for those who are willing to act and look the part of consumer tourist. The various surveillant apparatuses still exist as they did in the modern internment camps, but now individual subjects choose to enter and be watched in the hopes that the presence of the camera and sensors will protect them from the strangers and outcasts they fear.

What I want to make explicit at this point is how the logic of panopticism has been inverted in this new urbanism. The social outcasts are no longer quarantined off to be rehabilitated in an intensified experience of surveillant self-discipline. Rather, if the social outcasts don't fit the profile the camera is looking for then they are simply filtered out of view. The mechanization of surveillance is no longer for the outcast, homo sacer. Rather, the perfect society for all has been replaced by the safe society for the consumer elite who can afford to maintain a presence in camp Disney.

As with concentration camps, to understand them fully we need to look at the forms of citizenship being fostered in camp Disney. To this end, I want to suggest that in this new urbanism homo sacer becomes "the invisible flâneur." 36 The flâneur is the wanderer who experiences the alienation of the city in an intensified way. Instead of playing the game according to the rules of the machine, he becomes the man of the street. In Elizabeth Wilson's discussion of the flâneur she picks up on Walter Benjamin's study of Charles Baudelaire. ${ }^{37}$ "Baudelaire aligned himself with all the marginals of society - with the prostitutes, the ragpickers, the drunkards. It is not unusual for a rebel of his class to identify with the 'lumpen' part of society." 38 The flâneur is in some ways a less threatening way to name the homo sacer of the concentration camp. He wanders due to the isolation and anomie he experiences. He doesn't fit the norms. His life is one of marginalization. Paradoxically, by their nature the flâneurs seek out the crowd in order to secure their own isolation. ${ }^{39}$ Ironically this is the crime for which they are most guilty in camp Disney. Rather than become special or concentrated inside a camp, they are pushed to the margins and made invisible outside them. If they will not conform to the panoptic machine then they will be relegated from the gaze altogether. Crucially, the inverted panopticism of camp Disney intensifies the isolation and anomie of the flâneur.

\section{The Hidden Costs}

"Safety, security and social order are all seen by most people as positive accomplishments. Who would not wish to walk without fear on a street after dark?"40 Urban centers are often reliant upon tourism and consumerism which in turn relies on wealthy middleupper class people entering the city with the feeling of safety and security. We live in a world of terrorism and real crime that cannot be overlooked and must be taken seriously. City councils and local governments are therefore under pressure to provide the mechanisms necessary to ensure the security of urban spaces. As a result, surveillanced boundaries are being seamlessly extended throughout metropolitan areas. However, because governments often collude with the private sector to procure these goals, ${ }^{41}$ new categories of citizenship are being informed by the values of consumer tourism. In the quest for the freedom and safety to consume, individual subjects attempt to maintain a presence in the invisibly surveillanced zones of camp Disney. Those who fit the profile stay and remain "free." Those who don't are simply filtered into no-man'slands beyond the camera's view. ${ }^{42}$

\footnotetext{
${ }_{35}^{34}$ D. Sibley, Geographies of Exclusion: Society and Difference in the West (London: Routledge, 1995). 78

${ }^{35}$ Koskela, "The Gaze without Eyes: Video Surveillance and the Changing Nature of Urban Space." 137

${ }^{36}$ Elizabeth Wilson, "The Invisible Flâneur," in Postmodern Cities and Spaces, ed. Katherine Gibson (Oxford: Blackwell, 1995).

${ }^{37}$ Walter Benjamin, Charles Baudelaire: A Lyric Poet in the Era of High Capitalism, trans. H. Zohn (London: New Left Books, 1973).

38 Wilson, "The Invisible Flâneur." 73

39 "The flâneur only seems to break through this 'unfeeling isolation of each in his private interest' by filling the hollow space created in him by such isolation, with the borrowed - and fiction - isolation of strangers.... 'The pleasure of being in a crowd is a mysterious expression of the enjoyment of the multiplication of numbers." Benjamin, Charles Baudelaire: A Lyric Poet in the Era of High Capitalism. 58 citing Charles Baudelaire and Y. G. Le Dantec, Oeuvres, 2 vols., vol. 2 (Paris: Biblioteque de la Pleiade, 1931). 626

${ }^{40}$ Lyon, Surveillance Society: Monitoring Everyday Life. 53

${ }^{41}$ See for instance Mike Davis, City of Quartz: Excavating the Future in Los Angeles (London: Verso, 1990). Where he discuses the Haagen Development firm's redevelopment of the Martin Luther King Jr. Center in Watts district of Los Angeles. Following the completion of the King Center "he won the bid for the $\$ 120$ million refurbishing and expansion of the Crenshaw Plaza in Baldwin Hills, followed by a County contract to create a shopping complex in the Willowbrook area just south of Watts. In each case the guarantee of fail-safe physical security was the sine qua non in persuading retailers and franchises (and their insurers) to take up leases." 242. Davis points out the way in which local governments play a key role in colluding with private industry to create these surveillant centers. See also Lyon, Surveillance Society: Monitoring Everyday Life. 61

42 You can find these no-man's-lands in most major cities around the world. Throughout most urban centers you find pockets of undeveloped un-Disneyized sections where outsiders congregate. Sometimes these are clear ghettos like Skid Row in LA, but also the fenced off sections or condemned buildings, alleyways or under bridges.
} 
In the process of Disneyization, urban centers are fast becoming blinding simulacra - a matrix of images, symbols and glass that give the appearance of transparency when in fact they blind urban citizens from the dystopic life of the flâneur. Safe clean "“community' is nowadays another name for paradise lost - but one to which we dearly hope to return, and so we feverishly seek the roads that may bring us there. ${ }^{, 43}$ But at what cost? Surveillance apparatuses are being employed in ever greater numbers and in ever diverse ways in camp Disney and I'd like to suggest that the hidden cost is filtered out of view. Do we still have an obligation to the outcasts we cannot see? Can we develop further strategies of integration which counter the fragmenting nature of urban surveillance? Of course the answers to these questions are beyond the scope of what can be accomplished in an essay such as this, but I hope that any future conversations will take into account the political and social ideologies that current uses of surveillance entail.

\section{References}

Agamben, Giorgio. Homo Sacer: Sovereign Power and Bare Life. Translated by Daniel Heller-Roazan. Stanford: Stanford University Press, 1998.

Baudelaire, Charles, and Y. G. Le Dantec. Oeuvres. 2 vols. Vol. 2. Paris: Biblioteque de la Pleiade, 1931.

Bauman, Zygmunt. The Bauman Reader. Edited by Peter Beilharz, Blackwell Readers. Oxford: Blackwell Publishers, 2001. . Community: Seeking Safety in an Insecure World. Oxford: Blackwell Publishers, 2000. Modernity and the Holocaust. Ithaca: Cornell University Press, 2000.

Benjamin, Walter. Charles Baudelaire: A Lyric Poet in the Era of High Capitalism. Translated by H. Zohn. London: New Left Books, 1973.

Bentham, Jeremy. Panopticon. London: Reprinted and sold by T. Payne, 1791.

Bryman, A. "The Disneyization of Society." The Sociological Review 47, no. 1 (1999): 25-47.

Burgess, Ernest W. "The Growth of the City." In The Blackwell City Reader, edited by Sophie Watson. Oxford: Blackwell Publishers, 2002.

Davis, Mike. City of Quartz: Excavating the Future in Los Angeles. London: Verso, 1990.

Duncan, N. "Renegotiating Gender and Sexuality in Public and Private Spaces." In Bodyspace: Destabilizing Geographies of Gender and Sexuality, edited by N. Duncan. London: Routledge, 1996.

Festus, Pompeius. On the Significance of Words.

Foucault, Michel. Discipline and Punish: The Birth of the Prison. 2nd Vintage Books ed. New York: Vintage Books, 1995. - Power/Knowledge: Selected Interviews and Other Writings, 1972-1977. Edited by Colin Gordon. New York: Pantheon Books, 1980.

Funkenstein, Amos. Theology and the Scientific Imagination from the Middle Ages to the Seventeenth Century. Princeton: Princeton University Press, 1986.

Gorringe, Timothy. A Theology of the Built Environment: Justice, Empowerment, Redemption. New York: Cambridge University Press, 2002.

Hannigan, John. "Fantasy City: Pleasure and Profit in the Postmodern Metropolis." In Readings in Urban Theory, edited by Scott Campbell, 305-24. Oxford: Blackwell Publishers, 2001.

Hobbes, Thomas. Leviathan. Edited by Alfred Rayney Waller. Cambridge: Cambridge University Press, 1904.

Judd, D. R. "The Rise of the New Walled Cities." In Spatial Practices: Critical Explorations in Social/Spatial Theory, edited by D. C. Perry. Thousand Oaks: Sage, 1995.

Koskela, Hille. "The Gaze without Eyes: Video Surveillance and the Changing Nature of Urban Space." In Virtual Globalization: Virtual Spaces/Tourist Spaces, edited by David Holmes. London: Routledge, 2001

Lyon, David. Surveillance Society: Monitoring Everyday Life, Issues in Society. Buckingham: Open University Press, 2002.

Marcuse, Peter. "Not Chaos, but Walls: Postmodernism and the Partitioned City." In Postmodern Cities and Spaces, edited by Katherine Gibson, viii, 269 p. Oxford: Blackwell, 1995.

Matravers, Derek. "Introduction." In The Social Contract: Or Principles of Political Right, ix-xv. Ware: Wordsworth Editions Limited, 1998.

Milbank, John. Being Reconciled: Ontology and Pardon, Radical Orthodoxy Series. New York: Routledge, 2003.

Rousseau, Jean J. The Social Contract: Or Principles of Political Right. Ware: Wordsworth Editions Limited, 1998.

Shearing, Clifford D., and Philip C. Stenning. "From the Panopticon to Disneyworld: The Development of Discipline." In Perspectives in Criminal Law: Essays in Honour of John Ll.J. Edwards, edited by Anthony N. Doob. Aurora: Canada Law Book, 1984.

Shields, R. "Social Spatialization and the Built Environment: The West Edmonton Mall." Environment and Planning D: Society and Space 7 (1989): 147-64.

Sibley, D. Geographies of Exclusion: Society and Difference in the West. London: Routledge, 1995.

Warren, S. "Disneyfication of the Metropolis: Popular Resistance in Seattle." Journal of Urban Affairs 16 (1994): 89-107.

Wilson, Elizabeth. "The Invisible Flâneur." In Postmodern Cities and Spaces, edited by Katherine Gibson, viii, 269 p. Oxford: Blackwell, 1995

\footnotetext{
${ }^{43}$ Zygmunt Bauman, Community: Seeking Safety in an Insecure World (Oxford: Blackwell Publishers, 2000). 3
} 
Wolfe, Tom. "Pleasure Principles." New York Times, June 122005.

Zizek, Slavoj. Welcome to the Desert of the Real! London: Verso, 2002.

\section{About the Author}

\section{Timothy Stanley}

Timothy Stanley is currently a doctoral candidate at the University of Manchester under the supervision of Professor Graham Ward via an Overseas Research Scholarship from Universities UK. His research typically focuses on relating philosophical theology to contemporary culture. He is the author of "Punch-Drunk Masculinity" in "The Journal of Men's Studies" vol. 14 no. 2, "From Habermas to Barth and Back Again" in "The Journal of Church and State" vol. 48 no. 1, and "Redeeming the Icons" in "The Journal for Cultural and Religious Theory" vol. 6 no. 2. For his complete cv, please visit www.timothywstanley.com. 